\title{
An Assessment of the Utilisation of Social Media Mobilisation of Nigerian Youths in 2011 General Elections. A Case Study of Youths in Benue State.
}

\author{
${ }^{1}$ Alakali Terfa Titus-Fannie, ${ }^{2}$ Dr.Church Solomon Akpan, ${ }^{3}$ Tarnongo Moses O. \\ ${ }^{1}$ Research Fellow, Department of Mass Communication, University of Nigeria, Nsukka, Enugu State. \\ ${ }^{2}$ Senior Lecturer, Department of Mass Communication, University of Nigeria Nsukka, Enugu State. \\ ${ }^{3}$ Lecturer, Department of Mass Communication, University of Mkar, Mkar Benue State
}

\begin{abstract}
This study examines the utilisation of social media for the mobilisation of Nigerian youths during the 2011 General Elections. The survey research method was used with the questionnaire as instrument for data collection. Sample size for the study was 400 youths drawn from the ages between 18 to 40 years from the three (3) senatorial districts of Benue state. Findings revealed that political aspirants that used social media channels for campaigns had much support from the youths. The study recommended that the use of social media and other media should be complementary for the holistic mobilisation of the youths for political participation.
\end{abstract}

\section{Background of Study}

The role of the social media in political mobilisation and participation across the globe cannot be overemphasised. Of recent, the social media have been playing a leading role in mobilising support for or against unpopular leadership. Recent happenings in the Arab Countries especially in Egypt, Lybia, Tunisia etc have clearly demonstrated the effects of the social media on political mobilization of the youths to effectively checkmate leaders thus leading to their enthronement or dethronement.

It is also on record that, the recent London riots that took the ancient city by storm were hinged on the power of social media. Equally, the former American President, George W. Bush (Jnr) and the current American President, Barack Obama effectively used the social media channels like the Facebook, Twitter, You-Tube etc to mobilise electorates particularly the youths to support their political aspirations.

According to Narnia, B. and Charl ,V. (2011:2) "the term social media refers to web-based tools and services that allow users to create, share, and search for content and information without having to log on to any specific portal site or portal destination". These tools have become 'social' in the sense that, they are created in ways that enable users to share and communicate with one another. Social media are media for social interaction, using highly accessible and scalable publishing techniques. Social media use web-based technologies to transform and broadcast media monologues into social dialogues.

According to Amaefule (2011:20) "The Facebook, which is one of the first social media tools was launched in 2004 and has over 664.03 million users in about 233 countries worldwide". Since Facebook was launched, there has been massive interest from Africans to use the medium for different purposes especially among the youths. This observation has been echoed by Narnia Bohler and Charl (2010:12) thus:

Facebook is currently the most visited website by internet users on the African continent and currently 17 million people on the continent use Facebook. This may appear to be a small percentage, considering that the population of Africa which stands at over 1 billion, although it depicts an increase of 7 million from 2009.

The rapid growth of social media activities especially over the last three years is indicative of its entry into mainstream culture, and its integration into the daily lives of many people especially the youths. In the Nigerian political process, the use of social media became more pronounced in the 2011 General Elections especially among the youths. Most political aspirants in Nigeria including President Goodluck Jonathan, Mallam Nuhu Ribadu, Pastor Chris Okotie, used Facebook,Twitter, Naija Pals, Nairaland among others to engage the youths in discussing their political programmes and policies.

In Benue State, the 1on1.Com, Tivnet, the ATE-U-Tiv and Facebook were the most dominant social media channels used by the two dominant political parties-The Action Congress of Nigeria (ACN) and the Peoples Democratic Party (PDP) to send their campaign messages and interact with potential electorates during the electioneering period.

On Facebook, groups like Neighbour 2 Neighbour (n2n), Alliance for Good Governance, Arewa Christians' Initiative (ACI) among several others, were some of the most popular political groups found on the social media network during electioneering campaign in Nigeria. The influence of social media on youths' mobilisation is also captured by World Youth Report (2005:13) thus: 
It is becoming increasingly apparent that through modern day media, ICTs and global interconnectedness have combined to influence the lives of young people, creating what is referred to as global media driven youth culture.

The above statement shows the rate and speed at which the social media have taken a firm grip on the youths generally and will continue to influence their thinking pattern including political decisions. The relevance of the social media in our contemporary society is such that most leaders now maintain a Facebook, Twitter, 2go and Youtube account or even both to interact with the masses regularly. Today, Barack Obama, Goodluck Jonathan and a host of other presidents are on the Facebook for constant interaction with their subjects. However, it is not out of place for someone to ponder on the feelings, perception as well as reactions of the public over the new interactive strategy employed by many world leaders in reaching the general public especially the youths.

Again it is observed by scholars like Durkheim, E. (1982:13) that, in many social change experiences, the youths are mostly prone to reacting to change in two ways (i.e. acceptance or rejection) than other age categories of people. Therefore the introduction of social media in the political process is likely to be greeted by youth's reactions either positively or otherwise. The thrust of the paper therefore is an Assessment of the Utilisation of the Social Media on Political Mobilisation of Nigeria's Youths in the 2011 General Elections: A Case Study of Benue State.

\section{Statement of the problem}

Recently, Nigeria held its general elections that ushered in new leadership in the two tiers of government in the country. Apart from the other sources of information like the newspapers, magazines, radio and television, the social media were used as one of the viable medium which is interactive in nature. The social media offered some politicians an important platform in reaching many targeted electorates, especially the youths.

It is a statement of fact that social networking has become a very important tool for political mobilisation globally. It is gradually becoming a dependable tool in changing the opinions and influences of the public. Realising the efficacy of this medium, some Nigerian politicians quickly embraced it and exploited it extensively for their political campaigns in the 2011 general elections. According to Facebook Statistics (2010:2) "at least one million, seven hundred and fourteen Nigerians use the social media especially the Facebook, with a good number of them being young". However, there is no comprehensive knowledge of their activities as well as how this form of media can impact on various aspects of their political life. This study therefore investigates the role social media played in mobilising Nigerian youths in the 2011 General Elections, and the utilisation of the social media by different political aspirants.

\section{Objectives of the Study.}

The broad objective of the study is to explore and examine critically the extent to which the social media provides opportunity for people to send, receive and perceive messages relating to politics and politicking. The specific objectives of the study include the following:

(1) To assess the role of social media in creating political awareness to Nigerian youths in the 2011 general elections in Benue State.

(2) To assess the influence of social media on the voting pattern of Nigerian youths in the 2011 general elections in Benue State.

(3) To find out if social media is an efficient platform for youth's mobilisation for political participation.

(4) To compare the advantages of social media over the other forms of media for political mobilization.

\section{Research Questions}

Having outlined the objectives of the study, the following research questions were drawn:

(1) What is the impact of the social media on the voting pattern of Nigerian youths in the 2011 General Elections in Benue State?

(2) Do the social media increase the political awareness and consciousness of the youths in the 2011 General Elections in Benue State?

(3) Is social media an effective medium for mobilising Nigerian youths for political participation?

(4) What are the challenges of utilising the social media for political mobilization among theyouthsin Benue State?

\section{Significance of the Study}

First and foremost, it is hoped that this study will provide additional knowledge and literature on the topic understudy. It is also hoped that the study in its practical value will help government and other agencies both local and international in designing programmes that will promote good political process through the 
media. Similarly, it is hoped that this study will unravel other issues relating to social media and youths' participation in subsequent political process in Benue State and Nigeria in general. Finally, it is also hoped that this study will provide a stepping stone for further research in similar direction.

\section{Review of Related Literature \\ Empirical Studies on the Effects of social media on Global Politics}

The increasing effect of social media as a tool for social mobilisation and political support is being embraced globally. Omeruo, (2010:12) rightly notes that "social media is gradually detecting the pace of information-sharing and collaboration online and even in the real world, thereby making the traditional mass media to experience some decline in patronage especially among the youths". A study of the role of the social media in reporting the protest following the declaration of President Mahmoud Ahmadinejad as the winner of 2009 elections in Iran when the traditional media were banned from reporting the protests comes to mind. Omeruo, (2010:13) further noted that "it was such social media platforms like the Facebook, Myspece,Twitter, Flicker and YouTube among others that were used to disseminate information which attracted sympathy and interest from the international community"

Furthermore, Raacke and Bond-Raacke (2008:169) in their research titled "The youths and the use of social media" revealed that college students used social networking sites over nine times more than other segments of the population. Broeek, Pierson and Lieven, (2007:22) also found out that "individuals, ages between 18-24, spend more time on social networking than watching television" These researches confirm the fact that social media networks are dominantly used by the youths as in the case of our study area.

Apart from the above, other scholars have written on social media and political participation, some of these write-ups are reviewed in this study. In his research on "The effects of social media on youth's participation in politics", Meikle (2009:174) observes that: "The new change in the media industry have seen what he calls "Three dimensions of online news." The social media for instance, gives users the opportunity to present messages to the public in three folds thus "words - video clips - audio" Meikle (2009:175) further reveals that:

The BBC Hausa Facebook therefore is a forum where members interact and share information regarding a particular story from the BBC Hausa radio programme. They broadcast programmes in the morning, afternoon, and evening. The programmes are news and current affairs around the globe with a particular interest on African countries. The audiences of the programmes normally listen to the station at the broadcast hours. The introduction of the Facebook link allows listeners to access all the programmes of the station at any time they want via the internet.

With a link to the Facebook, one can as well see comments from different people, make their own contribution and also listen to the programmes they want. It can also be observed that people are getting more politically conscious via the use of the BBC Hausa Facebook. It therefore provides a platform for discussion, consumption of information, sending messages across the globe among others.

In their studies on "Blogs and Partisan Politics" Adamic,L. Glance,N. (2005:88) maintain that: "The John Kerry and George Bush political campaign teams adopted the use of blog. Incidentally, Bush's blog had more posts to prospective young adult voters than Kerry's". Ifukor (2010: 30) also notes that: "In 2008, Barack Obama and his campaign team also used blog and Twitter to disseminate crucial information about Obama's bid for the presidency". In a similar vein, Kelly and Etling (2008:15) revealed that:

The Iranian blogosphere liberalised political discourse in the face of a hostile media environment and Twitter was used by ordinary citizens to provide insider up-to-date information about the Iranian 2009 postelection protests.

Johnson, Kaye, Richard,and Wong,W. (2007:20) collaborated the above statement thus " because of its growing popularity for mediating political discourse, the credibility of blogs have been questioned and research shows that blogs were judged as moderately credible, but as more credible than any mainstream media or online source".

Another research conducted by Smith, C., McLaughlin, M. and Osborne, K. (1997:10) revealed that nearly three-quarter (73\%) of American internet users, or 54 percent of all voters went online in 2010 for news or information about mid term elections or to communicate with others about the campaign and the information voters are getting online, appears to have sway. Just one third of respondents said the information they saw online made them to vote for or against a particular candidate. Those results underscore the role that technology, but more specifically, social media networks like Twitter and Facebook will play in 2012 American presidential campaign, the report concluded.

Collaborating the above report, Ethan (2010:10) reports that, for politicians, social media is a communication tool that should be in most, if not all, political media strategies; it is a way for politicians to carry on a real time narrative directly with their constituencies particularly the younger generation at an affordable cost. Facebook and You-Tube enable politicians to continue their political narrative in a highly 
personal way, while Twitter and four squares give user's information to mobilise and show support at rallies and other meet ups. Also, taking a critical analysis of the capacity of the social media to effectively mobilise the masses for political participation in African countries, some critics have raised some pitfalls.

One of the scholars Shirky (2011:28) raises two arguments against the idea that social media can make a difference in the national politics of a state. It is important also to consider this side of the debate about the potential of social media to influence or bring about socio-political change on the African Continent. "The first is the fact that the tools themselves are actually ineffective, and second, that these tools can produce as much harm to any process of democratization as they can produce good".

The critique that social media can be ineffective has been mostly used by Malcolm Gladwell in The New Yorker and stems from the fact that casual participants to activities and actions such as large-scale social protests seek social change through low-cost activities such as joining a particular Facebook group like the "Save Darfur" group that was created on Facebook. Gladwell is of the opinion that such actions cannot bring about any useful action. Shirky (2010:29) however says that:

Even though this critique is correct, it is not central to the question of the power of social media in the sense that the fact that actors who are barely committed and who just joins Facebook groups and makes comments online does not mean that actors who are very committed cannot use social media effectively to influence socio-political change.

The second critique that social media tools can be used to influence or bring about socio-political change and political improvement has to do with the fact that the state is getting increasingly sophisticated and more technologically advanced means of monitoring and interdicting social media tools. Authoritarian states are increasingly shutting down communication networks and grids in their countries to deny dissidents the opportunity and resources to coordinate and broadcast documentation of any event in real time. It is thus necessary to point out that social media tools can and will be used as tools of state oppression.

However, the success of social networking in providing momentum and support to the popular uprisings in Tunisia and Egypt cannot be denied. In this context, Africa as a continent is experiencing a period of enormous change, and there is no doubt that social media will play a role in ensuring active continental political participation.

\section{The social media and 2011 Elections in Nigeria}

The increasing penetration of internet and telephone technology has culminated in an embrace of social media platforms by the Nigerian electorates, especially the youths who are increasingly becoming very vibrant and technology savoir-faire. To connect with this target group, Nigerian politicians had no choice but to leverage on the media platform through which they could be reached easily. Realising the impact of social media as a tool for political mobilization, the Goodluck Jonathan/Sambo Campaign Organisation (GJSO) effectively used the social media especially the Facebook and Twitter, to widen their political base especially among the youths as captured by Igbinidu (2010:2) thus:

Learning from the successful use of the social media platform by Obama and the desire to connect with the technology savvy Nigerian youth, President Goodluck Jonathan embraced it before he commenced campaigns for his party's ticket. In fact, he announced his decision to vie for the ticket using the instrumentality of Facebook. Not to be left out, other politicians jumped on the bandwagon.

This social link with Nigerian youths was actually a testing ground for the President to test his acceptability among Nigerians among the youths and it proved as a stepping stone to launch his bid for the 2011 presidency. The outcome of the impact of social media on political participation is further highlighted by Facebook statistics (2010:3) that:

To connect with this target group, Nigerian politicians had no choice but to leverage on the media platform through which they could be reached easily. President Goodluck Jonathan of Nigeria joined Facebook about 10 months ago, and was able to attract over 100,000 fans in less than 20 days. At present, he has over 500, 000 fans on the social networking site. His current Facebook fan base number places him second only to that of United States' President Barack Obama among other world presidents on Facebook. With only about 3 million home-based Nigerians on Facebook .

For those that used the social media platform very well, they were able to spread their messages fast. While many employed the conventional media like newspapers to get political information about the candidates, they also went to the internet and used social networking sites to see which politicians people they knew were supporting. The information gleaned from their social networks in some cases was the information they found most convincing and swaying.

It is also pertinent to mention that the use of social media was not limited to engaging supporters. On a daily basis, eligible voters used social networking sites to discuss political issues, voting procedures, the strengths and weaknesses of different candidates, and why they felt some candidates would win and others would not. After the announcement of results in polling units, many Nigerian voters also used Facebook and 
other social networking sites to send and discuss the results of their polling units. Even before the results were officially announced, it was easy to know which politician was doing well in different areas. Some scholars also viewed social media as possessing both the positive and negative attributes. According to Miller and Sarah (1997: 59):

It has been noticed that when politicians are candidates, they have this incentive to be engaging online, to be very active through social media communicating with voters to win them over. And then, when they get elected, their outreach through social media becomes stilted - it reads much more like a press release.

It is evident that, social media is a powerful tool for political mobilization and support but sustainability or the ability of Nigerian politicians to engage the youths to discuss major national decisions is always lacking. However, experience has shown that the 2010/2011 revolutions in Tunisia, Egypt, Syria and Libya were largely organized, supported and driven through the use of social media-based tools.

Facebook, Twitter and mobile phone technology inter alia allowed for extensive political expression against government, corruption both on- and offline. Calls for socio-political transformation heard on the streets of Tunis and Cairo were echoed around the globe, gaining much sympathetic support internationally. The recent events in North Africa may be a sign of things to come for the rest of the continent as technology continues to reach more Africans. Also commenting on the effects of social media on traditional media generally Dominick, (2009:293) identified some of the implications of the internet and its features thus:

The implications include a situation where the internet will become supplementary component of the conventional media fulfilling their roles in the society for instance blogging, Facebook, which allow users to pour comments based on their various interest. Dominick likewise identifies the internet as wiping off functions of gatekeepers.

This implication can result in having all sorts of information transmitted to the audiences unfiltered. Another social media network commonly used among the Nigerian youths for political participation is Nolitics. Nolitics is a politically-oriented discussion forum in the NaijaPals online community website. The term 'Nolitics' is portmanteau word (or coinage) from 'Naija Politics'. 'Naija' (also written as 9ja) is a clipped version of 'Nigeria'.

The forum generally maintains and promotes social discourse - where members post and receive comments on current social and political topics in Nigeria. Interactions are usually among young people who presumably have equal rights to share information and express their opinions. Members not only post comments, they also engage in some forms of social analyses and criticisms of Nigeria's socio-political system. Thus, participants lend their voices on topical issues that shape the society. Ifukor (2010) states that:

The dialectical relationship between discourse and social practice, and the process of political empowerment can be textually illustrated through the choice of vocabulary and sentiments expressed in blogs or discussion fora. Posts/journals on Nolitics are similar to blogs, which are frequently-updated and arranged in reverse chronological order.

Herring (2004:85) notes that "Social interactions are facilitated through user profiles containing biographical and contact information". Kouper, (2010:90) says "Users sign in to the hosting site with their private usernames and passwords". A close analysis of how meaning is made in some specific discussion fora in relation to the social context is likely to reveal opinions and different ways of thinking about governance and political participation.

Modern democratic principles demand that the people are involved in political governance, especially on issues that affect their lives directly or indirectly. Furthermore, Ifukor (2010:81) analysed the political discourse and social interaction by members of Nolitics. One of the first studies in this direction centres on the use of political blogs as social mobilization in the 2007 general elections in Nigeria. The study concludes that 'weblogs are influential political tool for mobilization and Nigerian bloggers have made use of them to educate, enlighten, and encourage eligible voters to perform their civic duties. Ifukor (2010:82) concluded that, "citizen's access to electronic social media empowers them to active involvement in democratic governance"

\section{Theoretical Framework}

Different scholars have postulated several theories on the power of the new technology and social media. Although most of them are relevant, however this study is anchored on Technological Determinism Theory.

\section{The Technological Determinism Theory}

Technological determinism is a reductionist theory that presumes that a society's technology drives the development of its social structure and cultural values. The term is believed to have been coined by Thorstein Veblen (1857-1929), an American sociologist. The most radical technological determinist in America in the twentieth century was most likely Clarence Ayres who was a follower of Thorstein Veblen and John Dewey. William Ogburn was also known for his radical technological determinism. Most interpretations of technological determinism share two general ideas which Sparks G. (2002:2) noted that: 
The development of technology itself follows a predictable, traceable path largely beyond cultural or political influence, and that technology in turn has "effects" on societies that are inherent, rather than socially conditioned or produced because that society organizes itself to support and further develop a technology once it has been introduced.

Strict adherents to technological determinism do not believe the influence of technology differs based on how much a technology is or can be used. Instead of considering technology as part of a larger spectrum of human activity, technological determinism sees technology as the basis for all human activity. Marshall (1982:15) posited that "societies have always been shaped more by nature of the media with which people communicate than by the content of the communication". In summary, Marshall was of the opinion that "the medium is the message". This statement could be used as a peg for the reason why most youth surf the net or join the social networks.

Many young people do not really have a clear cut objective of visiting the internet, but because he or she believes a friend is hooked on the internet, it becomes a mis-nomer for him or her not to be online. As the youths surf the net they join some social networks and consequently participate in political debates and other politically related activities. As they do so, they consciously or unconsciously participate in the political process. This informs our reason for anchoring the study on the technology determinism theory.

\section{Research Methodology}

The researcher adopted the survey research design for this study. This is because it was the most appropriate method that facilitated data collection for the study.

\section{Population of the Study}

The population of this study was limited to Benue State which has a population of 4,219,244(2006 Census). The youths constitute about 65 percent of the total population. Youths for the study constitute respondents whose ages falls in the range of 18-40 that used different social media networks in all the three (3) senatorial districts of Benue State.

\section{Sample Size}

The sample size for the study was 400 drawn from the three (3) senatorial districts of Benue State. The three senatorial districts include: Zone A comprising of seven Local Government areas namely: Vandeikya, Konsisha, Kwande Ushongo, Ukum, Katsina-Ala and Logo Local Government Areas. Zone B has seven Local Government Areas which are: Gboko, Buruku, Tarkaa,Makurdi, Guma, Gwer and Gwer West. Zone C senatorial district has the following Local Government Areas: Otukpo, Ohimini, Oju, Obi, Ogbadibo, Apa, Agatu, Ado and Okpokwu Local Government Areas.

The researcher purposively selected two towns in each of the senatorial districts based on access to internet facilities and higher institutions in existence. In Zone $\boldsymbol{A}$ Senatorial District, the researcher purposively selected Katsina-Ala and Adikpo towns, in Zone B, the researcher also purposively selected Gboko and Makurdi towns while in Zone C, the researcher adopted the same method to select Otukpo and Ugbokolo towns respectively. A total of 200 respondents constituted the sample.

\section{Sampling Procedure}

To select the respondents, the researcher randomly selected some cyber cafes where the youths or students of higher institutions frequent for internet services and used the purposive sampling technique to select the respondents. Thus a total number of 200 respondents were thus sampled from the population. Below is the distribution of the respondents based on selected towns.

Zone A: Adikpo / Katsina-Ala Towns

\begin{tabular}{|l|l|l|}
\hline S/No & Names of Institution/Café & No. of Copies of questionnaire Issued \\
\hline 1 & $\begin{array}{l}\text { First Phase Computer No.2 Shangev road } \\
\text { Adikpo West. }\end{array}$ & 20 \\
\hline 2 & $\begin{array}{l}\text { Big Shot Computers No.24 SASSA Street } \\
\text { Adikpo South }\end{array}$ & 15 \\
\hline 3 & BSU Adikpo Study Centre, ACC Adikpo. & 20 \\
\hline 4 & $\begin{array}{l}\text { National Teachers Institute, Adikpo } \\
\text { Study Centre }\end{array}$ & 15 \\
\hline 5 & Binto Café, No.5 COE Road K/Ala & 20 \\
\hline 6 & College of Education Katsina Ala & 10 \\
\hline 4 & Total & $\mathbf{1 0 0}$ \\
\hline
\end{tabular}




\begin{tabular}{|l|l|l|}
\multicolumn{2}{|c|}{ Zone B: Gboko/Makurdi Towns } \\
\hline S/No & Name of Institution/Cafes & No. of Copies of Questionnaire Issued \\
\hline 1 & $\begin{array}{l}\text { Wisden Computers/Café, No 3 Adekaa } \\
\text { Road Gboko Gboko Central }\end{array}$ & 30 \\
\hline 2 & $\begin{array}{l}\text { Fast Link Computers, Gyado White House } \\
\text { Gboko East }\end{array}$ & 25 \\
\hline 2 & University of Mkar, Mkar Gboko & 30 \\
\hline 3 & $\begin{array}{l}\text { Ashby Investment Café No.7 New Bridge } \\
\text { Road, Low Level, Makurdi. }\end{array}$ & 20 \\
\hline 4 & $\begin{array}{l}\text { Benue State University Makurdi Dept.of } \\
\text { Computer Sc./Stat }\end{array}$ & 20 \\
\hline 5 & $\begin{array}{l}\text { Benue State University Makurdi, Dept.of } \\
\text { Mass Communication }\end{array}$ & 30 \\
\hline 6 & $\begin{array}{l}\text { Federal University of Agriculture Makurdi } \\
\text { South Core }\end{array}$ & 25 \\
\hline 7 & $\begin{array}{l}\text { Federal University of Agriculture, Makurdi } \\
\text { South Core }\end{array}$ & 20 \\
\hline $\mathbf{8}$ & Total & $\mathbf{2 0 0}$ \\
\hline
\end{tabular}

Zone C: Otukpo/Ugbokolo Towns

\begin{tabular}{|l|l|l|}
\hline s/No & Names of Institutions/Cafes & No. of Copies of Questionnaire Issued \\
\hline 1 & $\begin{array}{l}\text { Inalem Computers No.14 Ibadan Street } \\
\text { Otukpo. }\end{array}$ & 20 \\
\hline 2 & $\begin{array}{l}\text { Open University, Otukpo Study Centre } \\
\text { Makurdi Road, Otukpo. }\end{array}$ & 25 \\
\hline 3 & $\begin{array}{l}\text { Benue Polytechnic Ugbokolo, } \\
\text { Okpokwu L.G.A. Benue State }\end{array}$ & 30 \\
\hline 4 & College of Education Oju & 25 \\
\hline & Total & $\mathbf{1 0 0}$ \\
\hline 5 & Grand Total & $\mathbf{4 0 0}$ \\
\hline
\end{tabular}

Note: The institutions and Cyber Cafes were chosen using the random sampling technique.

\section{Measuring Instrument}

The instrument used for data collection for this study was the questionnaire and interviews. It was designed in such a way that it will be easily understood by the respondents. About four interview questions were framed and given to the respondents in advance before the actual interview date fixed to allow the respondents have a full grasp of the issues for discussion. Two hundred (400) questionnaires were distributed in all the three Senatorial Districts of Benue State.

\section{Validity/ Reliability of Instrument}

Validation involves testing of validity and reliability of any instrument developed for data collection. It ensures what is intended to measure (validity) and that it can give constant results (reliability). The instrument for data collection in this study (the questionnaire and interview) were validated by pilot testing and by passing it through a cream of erudite scholars in the Department of Mass Communication, University of Nigeria Nsukka to ensure that it possesses both face and content validity. Besides, its reliability was determined using split-half method. The research instrument was administered once to a group of twenty (20) respondents after which it was divided into two equal halves comprising even numbered items and odd numbered items, which were scored separately. The two sets of scores were then correlated to obtain the internal consistency of the research instrument using Spearman's rank correlation. The calculated split half reliability coefficient of the instrument is 0.76

\section{Data Presentation/Analysis}

In this section data collected is presented and analysed using the frequency tables and simple percentages. The data is hereby presented below:

Table i: Gender of respondents

\begin{tabular}{|l|l|l|l|}
\hline S/No & Respondents & Frequency & Percentages \% \\
\hline 1 & Male & 220 & 55 \\
\hline 2 & Female & 180 & 45 \\
\hline 3 & Total & 400 & $100 \%$ \\
\hline
\end{tabular}

The table indicated that, 220(55\%) of the respondents are males while 70 (45\%) represent the female gender. The gap between the male and female is so close which is an indication that both sexes patronise the social media especially Facebook almost on equal proportion. 
Table ii: Age distribution of respondents

\begin{tabular}{|l|l|l|l|}
\hline S/No & Respondents & Frequency & Percentages \% \\
\hline 1 & $18-24$ & 80 & 20 \\
\hline 2 & $25-30$ & 150 & 37.5 \\
\hline 3 & $30-35$ & 70 & 17.5 \\
\hline 4 & $40-45$ & 60 & 15 \\
\hline 5 & $50-60$ & 40 & 10 \\
\hline 6 & Total & 400 & 100 \\
\hline
\end{tabular}

The table above shows the age distribution of respondents thus: $18-24$ is represented by $80(20 \%) 150(37.5 \%)$ $70(17.5 \%) 60(15 \%)$ while $40(10 \%)$ respectively. The analysis shows that the youths responded to these questions more than other age categories since they are the main target. The table shows that the age range between 18-35 responded to the questionnaire more than age range between 40-60. This tally with the researcher's observation that the youths used social media more than other ages under study.

Table iii: Marital Status of Respondents

\begin{tabular}{|l|l|l|l|}
\hline s/No & Respondents & Frequency & Percentages \% \\
\hline 1 & Single & 235 & 57.7 \\
\hline 2 & Married & 140 & 35 \\
\hline 3 & Divorced & 25 & 6.3 \\
\hline 4 & Total & 400 & 100 \\
\hline
\end{tabular}

The table clearly shows that single respondents were sampled more than other categories of respondents, this is represented by $235(57.3 \%)$ percent an indication that they use the social media for other purposes such as connecting with friends dating etc. The married people also have an impressive number represented by $140(35 \%)$ of the respondents while the divorced are $25(6.3 \%)$.

Table iv: Occupation of respondents

\begin{tabular}{|l|l|l|l|}
\hline S/No & Respondents & Frequency & Percentage \% \\
\hline 1 & Employee & 100 & 25 \\
\hline 2 & Self-Employed & 80 & 20 \\
\hline 3 & Unemployed & 100 & 25 \\
\hline 4 & Student & 120 & 30 \\
\hline 5 & Total & 400 & 100 \\
\hline
\end{tabular}

The table above shows the occupational distribution of the respondents. The statistics from the table showed that, the employee responses is represented by 100 (25\%) self-employed, $80(20 \%)$ unemployed, $100(25 \%)$ students $120(30 \%)$. The statistics is a clear indication that the students and the unemployed used the social media more than other categories of respondents. This is represented by $100(25 \%)$ and $120(30 \%)$ respectively. They could use is as part of their hobby or discuss other things apart from politics with their friends.

Table v: Have you registered with any of the social media?

\begin{tabular}{|l|l|l|l|}
\hline S/No & Respondents & Frequency & Percentage $\%$ \\
\hline 1 & Yes & 300 & 75 \\
\hline 2 & No & 100 & 25 \\
\hline 3 & Total & 150 & 100 \\
\hline
\end{tabular}

The table clearly showed that 300 being $(75 \%)$ of the respondents use one of the social media while only a negligible number $100(25 \%)$ don't use the social media. This is an indication that many of our respondents have the knowledge of the research topic and therefore had no problem responding to the questionnaire.

Table VI: If Yes which of the social media?

\begin{tabular}{|l|l|l|l|}
\hline S/No & Respondents & Frequency & Percentage $\%$ \\
\hline 1 & Facebook & 120 & 30 \\
\hline 2 & Twitter & 100 & 25 \\
\hline 3 & Nijapals & 80 & 20 \\
\hline 4 & Nolitics & 50 & 12.5 \\
\hline 5 & All of the above & 50 & 12.5 \\
\hline 6 & Total & 400 & 100 \\
\hline
\end{tabular}

The table above indicates that the number of social media networks being used by respondents. The statistics indicated an overwhelming usage of Facebook represented by 120 (30\%) followed by Twitter with 100 (25\%) 
Najipals $80(20 \%)$ Nolitics $50(12.5 \%)$ All of the above 50(12.5\%). The statistics which is an indication that Facebook is the most popular social media network in the study area.

Table vii: Do you prefer social to traditional media as a tool for political mobilisation in Nigeria?

\begin{tabular}{|l|l|l|l|}
\hline S/No & Respondents & Frequency & Percentage \% \\
\hline 1 & Yes & 200 & 50 \\
\hline 2 & No & 80 & 20 \\
\hline 3 & Both & 120 & 30 \\
\hline 4 & Total & 400 & 100 \\
\hline
\end{tabular}

The statistics shows that despite the massive use of social media among the respondents especially the youths, they still prefer the traditional mass media as the best tools for political mobilization. This is represented by $200(50 \%)$ of the respondents as against $80(20 \%)$ in favour the social media. While $120(30 \%)$ preferred both. This is an indication that proponents of social media for political participation still need to enlighten the masses on the efficacy of the social media.

Table viii: To what extent do the social media influenced youth's participation in 2011General Elections in Nigeria?

\begin{tabular}{|l|l|l|l|}
\hline S/No & Respondents & Frequency & Percentage $\%$ \\
\hline 1 & To a great extent & 280 & 70 \\
\hline 2 & Limited influence & 65 & 16.5 \\
\hline 3 & No influence & 55 & 13.5 \\
\hline 4 & Total & 400 & 100 \\
\hline
\end{tabular}

The above table is a clear indication that social media greatly influenced youths' participation in the 2011 General Elections. This is represented by $280(70 \%)$ of the total respondents. However, a negligible number of respondents being $65(16.5 \%)$ indicated that social media has limited influence, while the remaining $55(13.5 \%)$ said there is no influence at all. From these statistics it is clear that social media played a major part in influencing youth's participation in Nigeria's political process.

Table ix: Do you think with the social media the youths were better mobilised for political participation in 2011 than previous elections?

\begin{tabular}{|l|l|l|l|}
\hline S/No & Respondents & Frequency & Percentage \% \\
\hline 1 & Yes & 353 & 88.3 \\
\hline 2 & No & 47 & 11.7 \\
\hline 3 & Total & 400 & 100 \\
\hline
\end{tabular}

The table showed that social media played a major role in mobilising the youths for political participation especially in the 2011 elections. This is represented by $353(88.3 \%)$ of the total respondents while those that felt there was no contribution are represented by 47(11.7\%). This statistics shows that there is no significant difference seen in the role played by social media in the 2011 general elections above the previous elections in Nigeria since there is no major gap from the respondents.

Table x: Do you think the aspirants that used the social media had more followers than those that did not?

\begin{tabular}{|l|l|l|l|}
\hline S/No & Respondents & Frequency & Percentage $\%$ \\
\hline 1 & Yes & 300 & 75 \\
\hline 2 & No & 100 & 25 \\
\hline 3 & Total & 400 & 100 \\
\hline
\end{tabular}

The above table shows that $300(75 \%)$ of the respondents indicated that, political aspirants that used the social media channels for political campaign and youths mobilization had more followers than those that depended only on the known traditional mass media. Also other respondents represented by $100(25 \%)$ of the respondents maintained that social media did not increase the support base of its users more than non-social media users. However the result of the general elections showed that the PDP Presidential Candidate Goodluck Jonathan who used the social media had more national support base than his closest rival the CPC Presidential Candidate Gen. Mohammadu Buhari (Rtd.) who did not use the social media. 
Table xi: What are the impediments against use of social media in Nigeria's political process?

\begin{tabular}{|l|l|l|l|}
\hline S/No & Respondents & Frequency & Percentage \% \\
\hline 1 & Lack of internet access & 175 & 43.7 \\
\hline 2 & Low ICT literacy & 105 & 26.3 \\
\hline 3 & Lack of credibility on the web & 80 & 20 \\
\hline 4 & Poverty & 40 & 10 \\
\hline 5 & Total & 400 & 100 \\
\hline
\end{tabular}

The table indicated that all the factors listed above threaten the effective use of social media for Nigeria's political system. Factors like: lack of internet access top the list with 175(43.7 \%\%), Low ICT literacy $105(26.3 \%)$ Lack of credibility on the web $80(20 \%)$ while poverty stands at $40(10 \%)$. The statistics is an indication that all the factors listed impede effective use of social media for Nigeria's democratic process.

Table xii: How can the social media are sustained to promote democratic participation in Nigeria.

\begin{tabular}{|l|l|l|l|}
\hline S/No & Respondents & Frequency & Percentage \% \\
\hline 1 & Provision of more internet access & 200 & 50 \\
\hline 2 & More ICT Education & 150 & 37.5 \\
\hline 3 & Enhance internet security & 50 & 12.5 \\
\hline 5 & Total & 400 & 100 \\
\hline
\end{tabular}

The above table showed that all the mentioned variables are important in sustaining social media for the promotion of Nigeria's democracy. However the most important variable is the provision of more internet access which is represented by $200(50 \%)$ of the respondents. Another factor is the provision of more ICT education represented by $150(37.5 \%)$ while enhanced security is represented by 50(12.5\%) respectively. These variables are all important in sustaining the social media for democracy in Nigeria.

Table xiii: With the number of social media users, do you think Nigeria is ripe for electronic voting?

\begin{tabular}{|l|l|l|l|}
\hline s/No & Respondents & Frequency & Percentage $\%$ \\
\hline 1 & Yes & 80 & 20 \\
\hline 2 & No & 146 & 36.5 \\
\hline 3 & Undecided & 174 & 43.5 \\
\hline 5 & Total & 400 & 100 \\
\hline
\end{tabular}

From the table it is clear that Nigeria is not yet ripe for electronic voting as represented by 146 (36.5\%) of the respondents who said Nigeria is not yet ripe for electronic voting. However, $80(20 \%)$ of the respondents felt Nigeria is ripe for electronic voting while a large number of respondents represented by 174(43.5\%) are undecided. This statistics is a reflection that Nigeria still has a long way to go in achieving electronic democracy.

XIV. What motivated you to join the social media network?

\begin{tabular}{|l|l|l|l|}
\hline s/No & Respondents & Frequency & Percentage \% \\
\hline 1 & A Friend & 80 & 20 \\
\hline 2 & A Neighbours & 50 & 12.5 \\
\hline 3 & From the internet & 100 & 25 \\
\hline 4 & $\begin{array}{l}\text { Already exists on my Mobile } \\
\text { Phone. }\end{array}$ & 170 & 42.5 \\
\hline 5 & Total & 400 & \\
\hline
\end{tabular}

The statistics is an indication that a lot of factors motivated different respondents from using the social media. For instance 80 (20\%) were introduced to the use of social media by friends, 50(12.5\%) Neighbours, $100(25 \%)$ from the internet while majority had it already existed on their mobile phones.

Table XV: Did you get involved in political discussion on the social media in the 2011 general elections in Nigeria?

\begin{tabular}{|l|l|l|l|}
\hline s/No & Respondents & Frequency & Percentages (\%) \\
\hline 1 & Yes & 300 & 75 \\
\hline 2 & No & 100 & 25 \\
\hline 3 & Total & 400 & 100 \\
\hline
\end{tabular}

The table is a clear indication that most respondents were involved in the political discussion on the social media. This is represented by $300(75 \%)$ of the respondents, which is a clear indication that most of the 
respondents were engaged in political activities on the web. A negligible population represented by $100(25 \%)$ however were not involved in the discussion.

Table xvi: Assess the level believability of the social media by Nigerian youths with respect to political messages

\begin{tabular}{|l|l|l|l|}
\hline s/No & Respondents & Frequency & Percentages \% \\
\hline 1 & Very High & 58 & 14.5 \\
\hline 2 & High & 200 & 50 \\
\hline 3 & Moderate & 102 & 25.5 \\
\hline 4 & Low & 40 & 10 \\
\hline 5 & Total & $\mathbf{4 0 0}$ & $\mathbf{1 0 0}$ \\
\hline
\end{tabular}

The above table is an indication that respondents have some level of belief in social media with respect to political messages. The statistics shows that $58(14.5 \%)$ of the respondents have very high believe in social media messages, 200(50) indicated high while the remaining population indicated moderate believe represented by $102(25.5 \%)$ the rest shows low $40(10 \%)$ respectively.

Table xvii: Which major information do you seek on the social media?

\begin{tabular}{|l|l|l|l|}
\hline s/No & Respondents & Frequency & Percentages \% \\
\hline 1 & Social News & 150 & 37.5 \\
\hline 2 & Political News & 100 & 25 \\
\hline 3 & Sports News & 100 & 25 \\
\hline 4 & Entertainment News & 50 & 12.5 \\
\hline 5 & Total & $\mathbf{4 0 0}$ & $\mathbf{1 0 0}$ \\
\hline
\end{tabular}

The above table is a clear indication that most respondents seek social news on the social media more than other categories of information. This is represented by $150(37.5 \%)$, political news $100(25 \%)$, Sports News $100(25 \%)$ and entertainment news 50(12.5\%) respectively.

Table xviii: Freely express your feelings about the use of social media in Nigerian political system with reference to the 2011 general elections

\begin{tabular}{|l|l|l|l|}
\hline S/No & Respondents & Frequency & Percentages (\%) \\
\hline 1 & $\begin{array}{l}\text { Its enhances intellectual involvement of } \\
\text { the youths in the political system }\end{array}$ & 211 & 52.7 \\
\hline 2 & $\begin{array}{l}\text { Its provides another platform } \\
\text { for seeking political information }\end{array}$ & 80 & 20 \\
\hline 3 & $\begin{array}{l}\text { Its exposed the youths to political } \\
\text { system in Benue State }\end{array}$ & 78 & 19.5 \\
\hline 4 & $\begin{array}{l}\text { It's a forum for the political class to } \\
\text { engage the electorates. }\end{array}$ & 31 & 7.8 \\
\hline 5 & Total & $\mathbf{4 0 0}$ & $\mathbf{1 0 0}$ \\
\hline
\end{tabular}

The above table shows that $211(52.7 \%)$ of the respondents felt that the social media enhances intellectual involvement of youths in the political system. Similarly, other respondents felt that social media provides another platform for seeking the political information while $78(19.5 \%)$ are of the opinion that it exposed the youths to political system in Benue State while the remaining respondents 31(7.8\%) are of the opinion that the forum provides the political class an avenue to engage the electorates

\section{Discussion of Findings}

The major thrust of this study was to assess the utilisation of social media for the mobilisation of Nigeria's youth's in 2011 General Elections. In order to determine the impact of social media on youth's participation in the 2011 political process in Nigeria, Table viii shows that $280(70 \%)$ of the respondents felt that social media greatly impacted on youth's participation to the political process. This statistics is supported by Chioma (2011:2) thus:

I couldn't agree more. Conversations on real issues affecting Nigerians have started online, and continue offline in town hall meetings, concerts, religious gatherings and schools. It is obvious that regardless of who wins or loses, the April 2011 elections usher in a new dispensation of politicking that go beyond rallies, bribes, and noise to intellectual conversations about what people seeking office have to offer the people with the right/power to put them in those offices. 
This statement is an indication that social media influenced youth's participation to the democratic process in Nigeria. The social media also sets agenda for public discourse beyond online but to conventional meeting zones. To determine whether the social media detected the voting patterns of Nigerian youth's, Table viii and ix showed that $353(88.3 \%)$ indicated that the social media influenced their voting pattern.

To determine the effectiveness of the social media as a tool for mobilising youths for political participation, Table vii showed that 50(33.3\%) of the respondents felt that social media have being effective in mobilizing the youths for political support. However, the relevance of other traditional mass media cannot be undermined due to some constraints posed by the social media.

From the analysis, it was glaring that social media have played a major role in the Nigerian political system among the youths. Nigerian youths expressed their opinion on the political situation and the candidates of their choices freely on Facebook, Njapals, Ate-u-Tiv, 1on1.com among other social media channels in the 2011 General Elections in Nigeria.

\section{Summary}

Based on the findings from the study, evidence are glaring that social media have tremendous influence on the activities of Nigerian youths. A survey carried out indicated that most youths in the study area are members of various social media channels especially the Facebook, 1on1.com, Nijapals among others where they follow political debates, like the debate on zoning of the Presidency in the Peoples Democratic Party (PDP).

Other political discussions also feature on this forum and the youths follow keenly the debates, the campaign messages and online chatting with the candidates that register on the social media network. By doing, so they take decisions based on their convictions concerning who to support and how to get involved in the political process.

\section{Conclusion}

Social media forum provides an ample opportunity for Nigerians to participate in social and political interactions/debates. This reveals the willingness of the people to participate in political matters that affect them; it also highlights the need to make political governance accessible to people. Because online social media have the advantage of combining speed and currency with the facility that enable a synchronous computer-mediated discourse (CMD) to be stored and archive messages at the addressee's site until they are read, interactants are able to monitor and follow-up socio-political debates to their conclusions.

Discussion forum enable participants within and outside Nigeria to disseminate their views on important political issues while remaining anonymous. We can conclude therefore that the emergence of the online social media like Facebook and other discussion fora is enabling Nigerians to be involved in political debates much more than ever before. More voices are being heard, social problems are being discussed and more people are participating in political debates especially the youths.

This form of social and political participation is likely to increase in the future since online awareness is already created and bloggers are getting involved in computer-mediated discourse. Political involvement and participation in governance defines the concept of citizenship in the context of political discourse on Facebook, Nijapals, and Nolitics etc. Interestingly, with Nigerian politicians coming on Facebook and registering their own blogs, there is no doubt that the general influence generated from contributions by the people via the social media, would shape social morality and political performance.

\section{Recommendations}

Social media no doubt have massive patronage among Nigerian youths. However, most of them use the channels for social interaction more than other purposes, so, if there is sustained awareness on the use of the channels and politicians are encouraged to use it as one of the media for reaching the electorates, more people will turn to social media for political discussions, debates and opinions. It will actually serve as a medium for participatory democracy.

Credibility of social media should be encouraged because presently, most political stories obtained on the web are mere gossips and rumours which most a times are baseless. A little bit of caution should be exhibited by those who post comments unto these social media sites. This is because; some of these comments are derogatory and appalling.

Finally, relevant bodies should enact some laws and regulation guiding the operations of social media.

\section{Books}

\section{Bibliography}

[1] Broeek, W. Pierson, J. \& Lievens, and B. (2007) Videos on Demand: Towards New Viewing practices? Observation Journal No.3

[2] Dominick, J. R. (2009) The Dynamics of Mass Communication, Media in the Digital Age (10th Edition). London: McGraw-Hill.

[3] Dominick J.and Wimmer R. (2006) Mass Media Research: An introduction (9th ed.).Wadsworth. Publishers. 
[4] Durkheim, E. (1982). Rules of Sociological Methods. New York: Free Press.

[5] Flew T. (2005) New Media, an Introduction. U.S: Oxford University Press

[6] Herring, S. (2004) 'Computer-Mediated Discourse Analysis: an Approach to Researching Online Behaviour. In S.A. Barab, R. Kling \& J. Gray (Eds.), Designing for Virtual Communities in the Service of Learning. New York: Cambridge University.

[7] Kelly J. and Etling, (2008). Mapping Iran's Online Public: Politics and Culture in the Persian logsphere. Berkman: Center Research Publication, No. 2008-01, Harvard University. Press.

[8] Marshall, M. (1982) All That Is Solid Melts into Air: The Experience of Modernity. New York: Simon and Schuster.

[9] Sparks G.G. (2002) "Media Effects Research" Canada: Wadsworth Publishers

\section{Journals, Newspapers, Workshops and Internet Sites}

[10] Adamic L. and Glance N. (2005). 'The Political Blogosphere and the 2004 U.S Election Divided they Blog.'2nd Annual Weblogging Workshop, WWW 2005, May 10, Chiba, Japan.

[11] Essoungou, A.M. (2010.) "A social Media Boom Begins in Africa” in Africa Renewal (online edition), December 2010

[12] Ethan,L.(2010)UsingSocial Media to Rally Support. Retrieved from http:www.sparxoo.com/2010/06/17using Social -media-to-rallysupport-for politicians.

[13] Facebook Usage Statistics (2010:5) http://www.nickburcher.com/Facebook-usage.Statistics-March-2010.htm accessed 28 February 2011].

[14] Igbinidu C. (2011) Social Media and the 2011 Elections in Nigeria. www.socialmedia2011.

[15] Miller and Sarah (January 1997). "Futures Work - Recognising the Social Determinants of Change Social Alternatives (Vol.1 No.1 ed.). -58 .

[16] Narnia Bohler-Muller and Charl van der Merwe (2011) The Potential of Social Media to Influence Socio Political Change on the African Continent. Africa Institute of South Africa Briefing. No 46 March 2011.

[17] Omeru, K (2010) "New Technologies and 2011 Elections" The Punch.December 12, P.12

[18] Raacke, J. \& Bonds-Raacke, J. (2008) "My Space and Facebook: Applying the use and Gratifications Theory of Exploring FriendNetwworking Sites" Cyber-Psychology \& Behaviour: Vol.11 No.2

[19] Shirky C.( 2011) The Political Power of Social Media: Technology, the Public Sphere and Political Change' in Foreign Affairs, Volume 90 .

[20] Smith, C. McLaughlin, M. and Osborne, K. (1997). "Conduct controls on Usenet" Journal of Computer- b Mediated Communication, 2(4).www.ascusc.org/jcmc/vol2/issue4

[21] KouperI.(2010)“ThePragmaticsofPeerAdviceinaLivejournal Community.Language@Internet7, Article 1, www.languageatinternet.de.

[22] Johnson T. Kaye B. and Wong W. (2007). 'Every blog has its day: Politically-interested Internet users' perceptions of blog credibility. Journal of Computer-Mediated Communication, 13(1), Article World Youth Report, (2005) Youth in the civil Society (Part Two).

[23] Chioma I.(2011) Social Media and the New Dimension to Nigerian Politic Posted on March 21, 2011. 